\title{
An assessment of oceanic seabird abundance and distribution off the southern Brazilian coast using observations obtained during deep-water fishing operations
}

\author{
Branco, JO. ${ }^{a *}$, Fracasso, HAA. ${ }^{b}$, Pérez, JAA. ${ }^{a}$ and Rodrigues-Filho, JL. ${ }^{b}$ \\ ${ }^{a}$ Centro de Ciências Tecnológicas da Terra e do Mar, Universidade do Vale do Itajaí - UNIVALI, Rua Uruguai, \\ 458, Centro, CP 360, CEP 88301-970, Itajaí, SC, Brazil

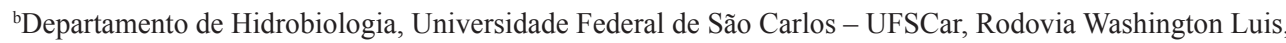 \\ Km 235, CP 676, CEP 13565-905, São Carlos, SP, Brazil \\ *e-mail: branco@univali.br
}

Received: July 16, 2012 - Accepted: March 29, 2013 - Distributed: November 30, 2014

(With 7 figures)

\begin{abstract}
The use of discarded fish over baited hooks used in longline fishery, and fish caught in gillnets, as a food source for gulls, albatrosses and petrels has been intensively studied in northern and southern oceans. This study describes the occurrence and abundance of seabirds observed from 20 foreign vessels which operated during the period between July 2001 and May 2005, off the southeastern and southern Brazilian coast. A total of 353,557 seabirds were observed; comprising eight families and 28 species. The most abundant species was Procellaria conspicillata followed by Daption capense, Puffinus gravis, Thalassarche melanophrys and Oceanites oceanicus. Ten species of seabirds (392 individual birds) were incidentally captured in gillnets; and 122 birds ( 9 species) by longline hooks, with P. gravis, D. capense and Procellaria aequinoctialis having the largest capture rates.
\end{abstract}

Keywords: oceanic seabird, vessels operations, on board observers, Brazil.

\section{Uma avaliação da abundância de aves marinhas oceânicas e distribuição do Sudeste e Sul do Brasil a partir de observações durante operações de pesca em águas profundas.}

\section{Resumo}

A utilização dos descartes sobre as iscas dos anzóis em pescarias de espinheis e peixes capturados por redes de deriva como fonte de alimento por gaivotas, petréis e albatrozes têm sido intensamente estudados nos Oceanos Norte e Sul. Este trabalho tem como objetivo registrar a ocorrência e abundância das aves marinhas observadas a partir de 20 embarcações estrangeiras arrendadas que atuaram durante o período de julho de 2001 a maio de 2005 na costa sudeste-sul do litoral brasileiro. Foi registrada a ocorrência de 353.557 aves marinhas distribuídas em oito famílias e 28 espécies, com a maior participação de Procellaria conspicilatta, seguido de Daption capense, Puffinus gravis, Thalassarche melanophrys e Oceanites oceanicus. Foram capturadas incidentalmente 392 exemplares de aves marinhas pelas redes de emalhe e 122 pelos anzóis dos espinhéis, distribuídos em dez e nove espécies, respectivamente, com as maiores taxas de captura sobre $P$. gravis, D. capense e Procellaria aequinoctialis. Este estudo mostra uma pequena parcela das aves capturadas no litoral brasileiro, uma vez que as embarcações fiscalizadas representam a minoria das que estão em atividade. $\mathrm{O}$ acompanhamento de Observadores de bordo capacitados deve ser intensificado para avaliar o impacto das pescarias nas populações de aves marinhas, bem como implementar ações para diminuir suas capturas.

Palavras-chave: avifauna marinha, operações pesqueiras, observadores de bordo, Brasil.

\section{Introduction}

Fishing operations may interact with seabirds positively, by providing additional food (produced by discards), or negatively, due to non-intentional catch (Thompson, 1992; Bartle, 1991). The consumption of discards by gulls, petrels and albatrosses has been assessed in both the North and the South Atlantic Oceans (Furness et al., 1992; Thompson,
1992; Garthe and Hüppop, 1994; Thompson and Riddy, 1995; Garthe et al., 1996; Martinez-Abraín et al., 2002). As a downside, bait used on longlines, and fish (or other organisms) entangled in the gillnets attract seabirds, which may become victims of fishing gear. In fact, longline fishing has been regarded as the main source of albatross 
mortality worldwide (Brothers, 1991; Murray et al., 1993). Because it is conducted at such a large scale, longline fishing has been shown to reduce some bird populations to a threatened state (Weimerskirch et al., 1997). In addition, gillnets, another extensively-used fishing gear, have also been shown to cause significant unintentional catches and contribute to anthropogenically induced seabird mortality (DeGange and Day, 1991; Waugh et al., 1999).

Only two species of Procellariformes oceanic seabirds nest off the Brazilian coast. However, waters within Brazil's Exclusive Economic Zone (EEZ) are important foraging areas for pelagic species, which disperse from their Antarctic breeding colonies during the austral winter, and primarily concentrate around the subtropical confluence zone between March and October (Veit, 1995; Thomsen, 1962; Pocklington, 1979; Briggs et al., 1987; Ribic and Ainley, 1989; Neves and Olmos, 1997; Weimerskirch et al., 1997). The great biological productivity of the subtropical confluence zone, attracts not only birds, but also pelagic and demersal fishing efforts, thereby resulting in a great number of interactions between pelagic seabirds and fish boats (Neves and Olmos, 1997).

Assessing such interactions (both positive and negative) comprehensively has been a complex task achievable only through the intensive observation of fishing operations and the use of specific survey methods including species identification and census routines. These can hardly be performed by untrained and/or undedicated crew members and, in that sense, despite recent international efforts, our understanding of the distribution oceanic seabirds in Brazilian waters and their interactions with fishing activity is incipient (Vaske-Júnior, 1991).

Since the year 2000, a government-induced vesselchartering programme initiative has attracted foreign fishing fleets to the Brazilian waters which were not being used by the domestic fleet (Perez et al., 2003; Alvarez Perez et al., 2009). As part of the agreement between Brazil and the foreign fleets, these foreign vessels are required to carry observers during their operations in Brazilian waters, in order to collect data on: (a) the fishing operations and technology; (b) processing and handling practices; (c) distribution and abundance patterns of potential fishing resources; and (d) general impacts on the marine ecosystem (Alvarez Perez et al., 2009). The programme has provided an unprecedented opportunity to collect data on the characteristics and extent of bird and marine mammal bycatch as a function of the employed fishing methods.

Perez et al. (2003) produced a preliminary assessment of all the bycatch resulting from different fishing methods, specifically on the impact of the demersal gillnet monkfish Lophius gastrophysus Miranda-Ribeiro, 1915 fishery, including estimates of the total seabird mortality within the demersal gillnet fishery and bycatch rates within fishing zones near the southern limit of the Brazilian EEZ (Perez and Wahrlich, 2005).

In addition to seabird bycatch, a robust data set has been built containing observations of seabirds and marine mammals in the vicinity of the chartered fishing vessels, during their operations off the Brazilian coast. This paper summarises these data, and describes the oceanic seabird composition, abundance and distribution along the southeastern and southern sectors of Brazil's EEZ, and our hypothesis is that different fishing vessels attracted different species and number of seabirds in relation to the sub-areas along the Brazilian coast.

\section{Material and Methods}

\subsection{Area of study}

This study included data collected on board of chartered vessels operating off Brazil between parallels $22^{\circ}$ and $35^{\circ}$ S from July 2001 to May 2005. The Brazilian southeastern coast was divided into three subareas: the first was between $22^{\circ}$ and $25^{\circ}$, which includes the north of Rio de Janeiro to the south of São Paulo, the second between $25^{\circ}$ and $29^{\circ}$ (Paraná and Santa Catarina) and the third between $29^{\circ}$ and $35^{\circ} \mathrm{S}$ (Rio Grande do Sul) (Figures 1, 2, 3 and 4).

\subsection{Fishery operations and Census}

A total of 2.904 fishing hauls conducted with trawlers, potters, gillnetters and longliners were monitored by 69 observers who performed seabird counts throughout the entire study period. Slope trawlers operated mostly on the lower continental slope $(500-800 \mathrm{~m})$ between $22^{\circ}$ and $29^{\circ} \mathrm{S}$; primarily targeting deep-water shrimp (Family Aristeidae), as well as groundfish (monkfish, hake (Merluccius hubbsi Marini, 1933) and others (Alvarez Perez et al., 2009). The bottom gillnet fishery targeted monkfish operating on the slope off Brazil between 2001 and 2002 occupied southeastern and southern Brazil slope grounds between 300 and $600 \mathrm{~m}$ depths.

Pot vessels targeted deep-water crab (especially the red crab Chaceon notialis Manning \& Holthuis, 1989, and the royal crab C. ramosae Manning, Tavares \& Albuquerque, 1989 (Pezzuto et al., 2006) and long liners to Wreckfish Polyprion americanus Bloch \& Schneider, 1801 , at the $30^{\circ} \mathrm{S}$ between 159 and $800 \mathrm{~m}$, and Pink Cusk-eel Genipterus brasiliensis (Regan, 1903), Tope shark Galeorhinus galeus (Linnaeus, 1758) and Tile fish Lopholatilus villarii (Miranda-Ribeiro, 1915).

During potter operations, seabirds were attracted to the vessels mostly by discarded crab offal (especially from red crabs) and damaged catch, resulting in 1,358 seabird counts made by 25 observers.

The bottom gillnet fishery operating (607 counts by 19 observers) on the slope off Brazil during the study period targeted the monkfish but produced an abundant unintentional catch mostly rejected as the nets were retrieved (same board), during a nearly 12-hour operation (Wahrlich et al., 2004; Perez and Wahrlich, 2005).

During the bottom trawling vessels, 17 observers made 761 counts of seabirds during the discard round of unwanted parts of the target species (tails, offal and carcasses) and by catch.

In long line boats, eight observers compiled 175 records of birds on the rejects (fish heads, tails and entrails) 

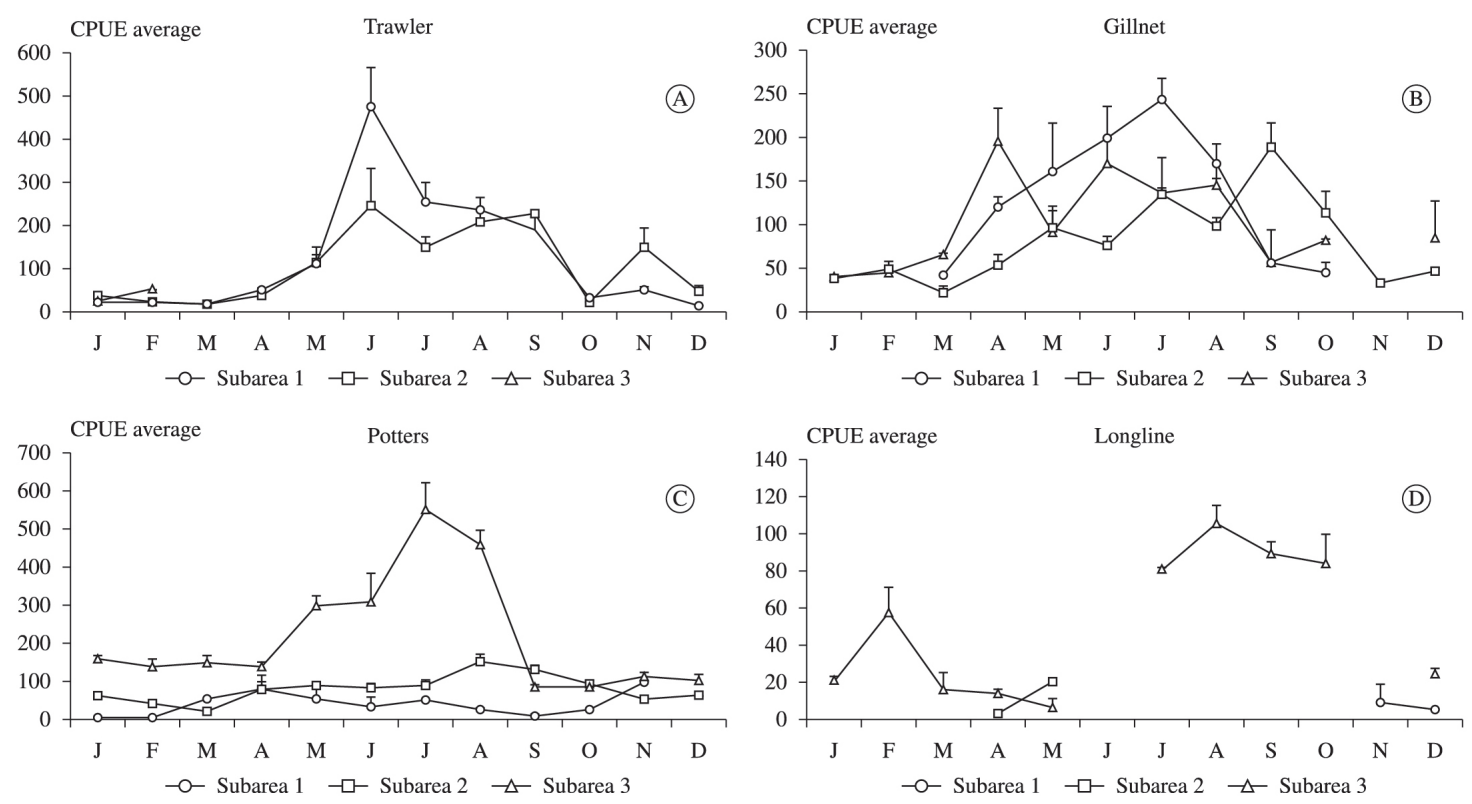

Figure 1. Total number of seabirds observed around different gear fisheries off the southern coast of Brazil, in subareas I, II and III. Trawler (A), Gillnet (B), Potter (C) an Longline (D).

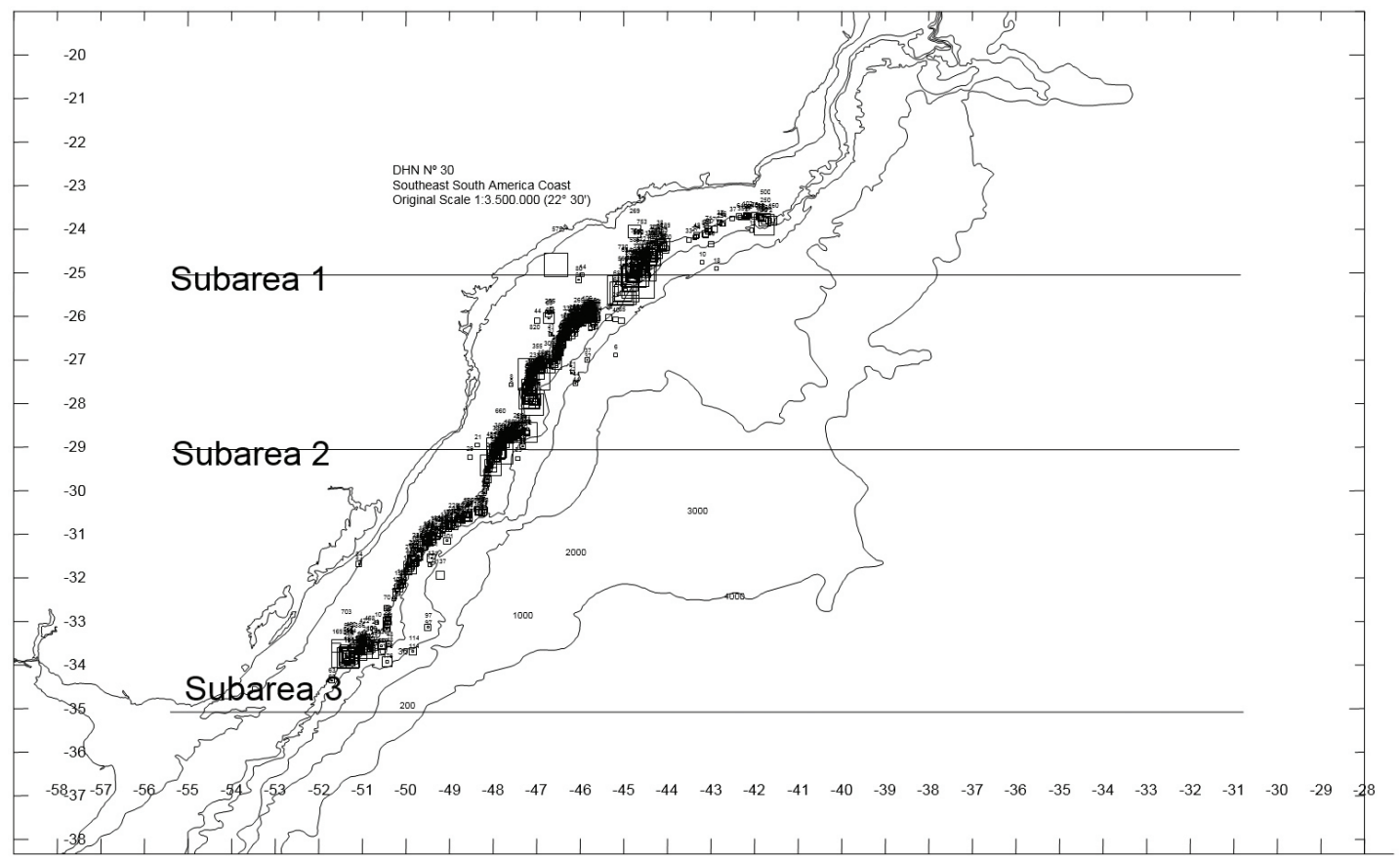

Figure 2. Occurrence of seabirds around gillnet fishing, in three subareas along the Brazilian coast.

discarded on the opposite side of the vessel in which the lines with baited hooks were released. This modality has sought to reduce the incidental capture of seabirds using the launch night and the line bogey (or scare tore lines).

During the vessel trips, spreadsheets, weighing and measuring instruments, seabird identification manuals (Vooren and Fernandes, 1989; Harrison, 1996; Onley and Bartle, 1999), photographic records and videos, were all used on-board. Seabird counts around the boat were taken with the naked eye and $10 \times 50$ binoculars, when necessary, and the information stored in computers (Weimerskirch et al., 2000; Chiaradia, 1991).

\subsection{Data analysis}

The Catch Per Unit Effort (CPUE) as the standard measure used in this study was calculated based on the number of birds on each count in a radius of $500 \mathrm{~m}$ by $360^{\circ}$ around the vessel, and variable time according to 


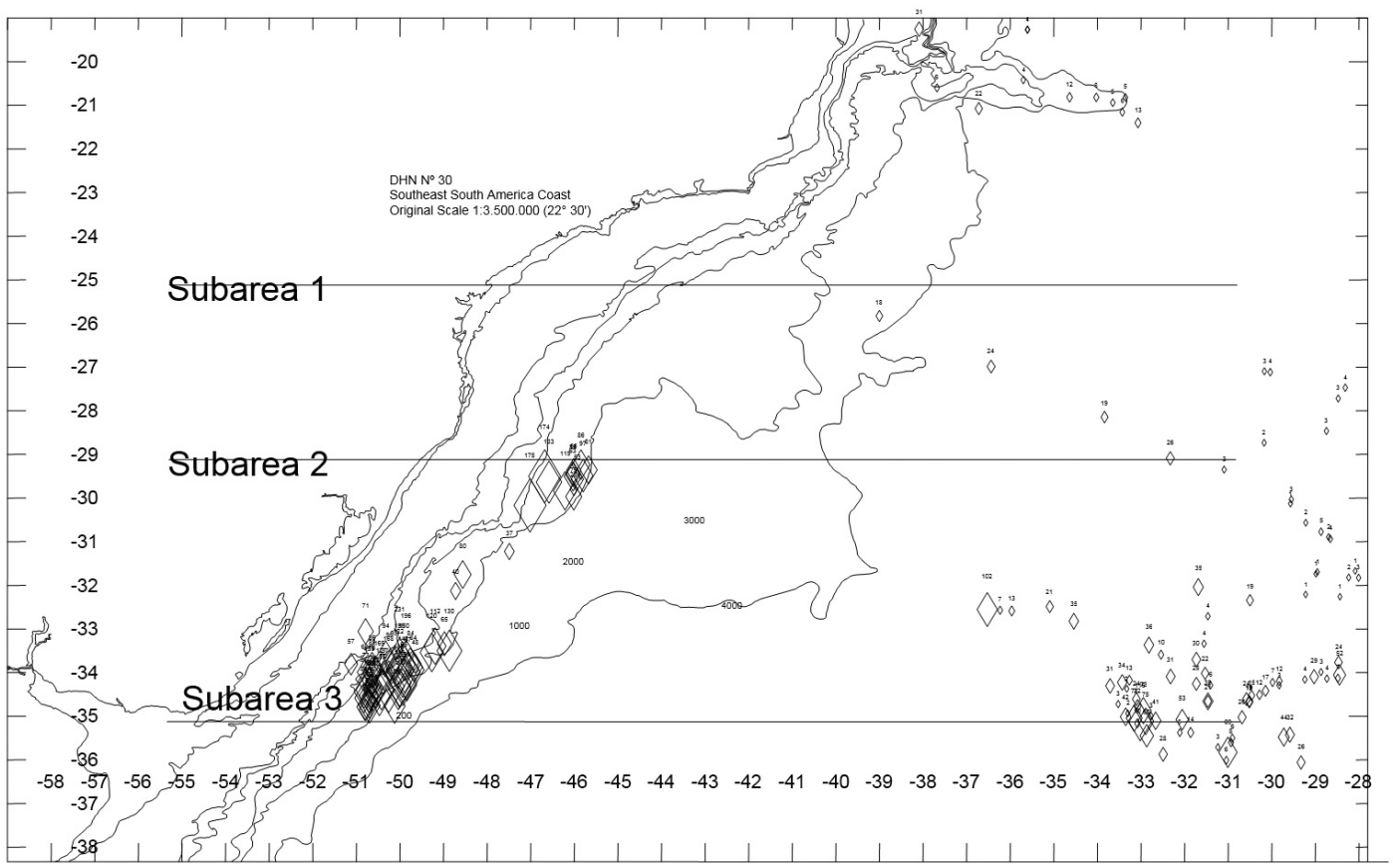

Figure 3. Occurrence of seabirds around longline fishing operations, in three subareas along the Brazilian coast.

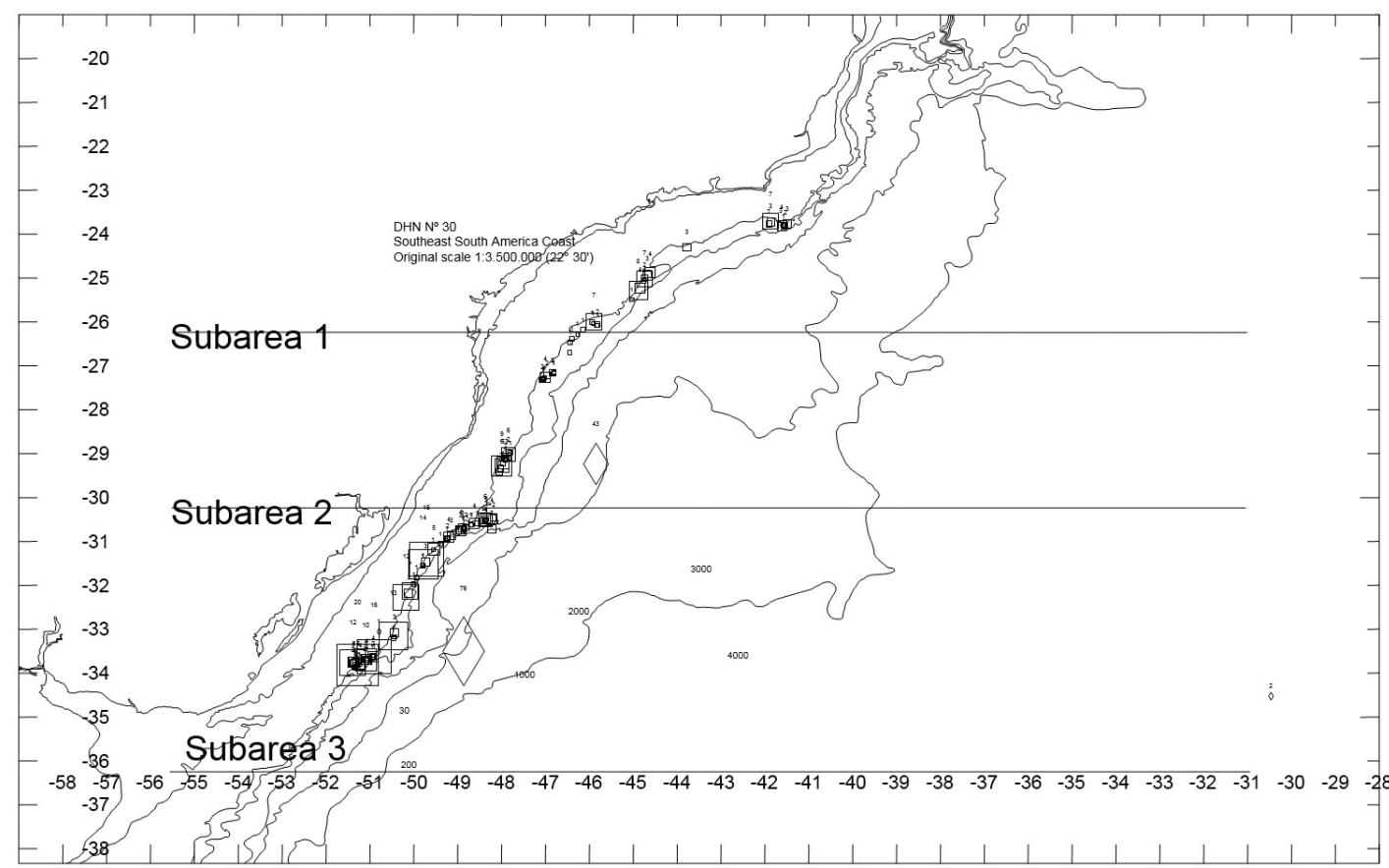

Figure 4. Occurrence of seabirds captured incidentally around gillnet and longline fishing, in three subareas along the Brazilian coast.

abundance. In the case of large concentrations of birds ( $>5000)$, values were estimated by the average of two random scores on the board of the waste disposal lasting 15 minutes (Weimerskirch et al., 2000; Chiaradia, 1991).

The CPUE data were divided into three sub-categorised and geocoded in proportion to the abundance of birds in the counts with the aid of the program SURFER 8.1.
The Chi-square (the "Instats", $p<0.0001$ and 36 degrees of freedom) was applied in order to test the association or independence between frequency of occurrence oscillation, average abundance of each bird species throughout the study period, in the various methods of fishing.

The totals of each species of birds sighted in different types of fishing were recorded, and tested under the 
influence of wind directions described as 0 (no wind), 1 (North wind), 2 (Northeast wind), 3 (Northwest wind), 4 (South wind), 5 (Southeast wind), 6 (Southwest wind), 7 (East wind) and 8 (West wind).

\section{Results}

During the fishing activities, 353,557 seabirds distributed in eight families and 28 species were recorded, where Procellaria conspicillata Gould, 1844, Daption capense (Linnaeus, 1758), Puffinus gravis (O'Reilly, 1818), Thalassarche melanophris (Temminck, 1828) and Oceanites oceanicus (Kuhl, 1820) contributed with $72.1 \%$ of birds along the Brazilian southeastern coast (Table 1).

Potter vessels attracted the greatest number of species and specimens, with a predominance of $D$. capense, $P$. conspicillata and O. oceanicus. Diomedea epomophora (Lesson, 1825), and Stercorarius parasiticus (Linnaeus, 1758) were seen only in this fleet, while the trawlers, ranked second in CPUE, with the predominance of $P$. gravis, T. melanophris and P. conspicilatta, followed by the gillnets (Procellaria, Calonectris diomedea Scopoli, 1769) and T. melanophris) and bottom long line (P. conspicilatta, P. gravis, D. capense) (Table 1).

All fishing gear attracted birds over monitored years, with seasonal fluctuations and abundance peak in gillnet vessels in 2002, trawlers and potters in 2003 and long line in 2004; independent of the vessel's equipment, the highest seabird concentrations were observed in October 2001, November 2002 and August 2004, July 2003 and January 2005 (Figure 5).

The mean CPUE recorded on trawler vessels was stable from January to April, with an increase from May to June and fall in the remaining period (Figure 1A). In the case of gillnet, the average seabird's CPUE swung erratically between subareas, with the highest rates occurring in subarea I during July, subarea II in September and subarea III in August (Figure 1B). The seabirds CPUE on potters in subareas I and II showed small fluctuations throughout the period, with the highest values in November and August, respectively, while in subarea III the highest rates were recorded in July, followed by a drop and oscillations to the period's end (Figure 1C). Despite the uneven performance of the longline fleet in the subareas, the fishing effort was higher on the third, with peak values of CPUE in February and August, and absence in June and November; Sub-area I and II was restricted to April and May and November and December, respectively (Figure 1D).

The greatest abundance of birds, which were directly related to the area and fishing effort of trawler vessels, occurred in subarea I, reducing considerably in subarea II and absent in subarea III (Figure 6).

The seabirds distribution along the coast was uniform, with the greatest abundance in subarea II, followed by III and I (Figure 2).

In subarea III, the highest abundance of birds were concentrated in the south, while in other regions they were distributed evenly, with gradual decrease toward the north (Figure 7).

The highest concentrations of seabirds were recorded nearest to the border between Rio Grande do Sul and Uruguay (Figure 3).

According to Table 2, a marked difference in the composition of birds in each modality $\left(\mathrm{c}^{2}{ }_{4-36}=10.5783\right.$, $\mathrm{p}<0.0001$ ) were recorded by independence of samples from seabird abundance, so these values are strongly associated to the type of vessels; $P$. a. conspicillata predominated in trawlers followed by T. melanophris and P. gravis, in gillnet by $P$. a a aquinoctialis and $P$. gravis and long line by $P$. gravis and $D$. capensis, except in potters (P. gravis) followed by $P$. a. conspicillata and O. oceanicus (Table 2).

During trawler operations, 13 species were sighted, and 10 were more abundant when a northeast wind was acting and only two (M. giganteus and D. crysostoma) stood out when the wind was southwest. The northeast wind was responsible for $40.51 \%$ of the total abundances and $F$. glacialoides showed higher values when there was no wind (Table 3 ).

In potters, a similar behaviour of birds in relation to trawlers, eight species were more abundant when the wind was northeasterly $(21.82 \%)$ and four in the southwesterly $(20.44 \%)$ (Table 3$)$. In the gillnet, the predominance of species occurred when the wind was northeasterly (10 species), and $D$. exulans showed higher registers when the wind was north, D. crysostoma when it was southeasterly and M. giganteus when it was southwesterly (Table 3). Finally, in the longline method (Table 3), the predominance of six species were recorded when the wind was northeasterly, followed by southwesterly.

\subsection{Incidental catches}

During the observations, 392 specimens of seabirds were incidentally captured by gillnets and 122 by longlines, distributed in ten and nine species, respectively, with the highest catch rates of $P$. gavis, D. capense and P. aequinoctiallis (Table 1). The fishing gear trawl vessels and potters not captured birds during the study period. Incidental catches recorded on board longline vessels were restricted to subarea 3, however, in gillnet vessels, these decreased directly proportional to the increase in latitudes (82 cases in III, 27 in II and 12 in I) (Figure 4).

\section{Discussion}

With growing competition for marine resources and chemical pollution of the oceans, the search for alternative food sources such as discharges of fisheries, baited hooks and fish caught in drift nets were strategies used by marine birds (Griffiths, 1982; Abrams, 1983; Hudson and Furness, 1989; Ryan and Moloney, 1988; Thompson, 1992; Moore, 1994; Garthe and Hüppop, 1994; Thompson and Riddy, 1995; Weimerskirch et al., 2000).

The waste comes from fish processing and the number of vessels operating in the same area directly affect the number of birds that are attracted, but the interactions are complex and probably also depend on the ecology and 


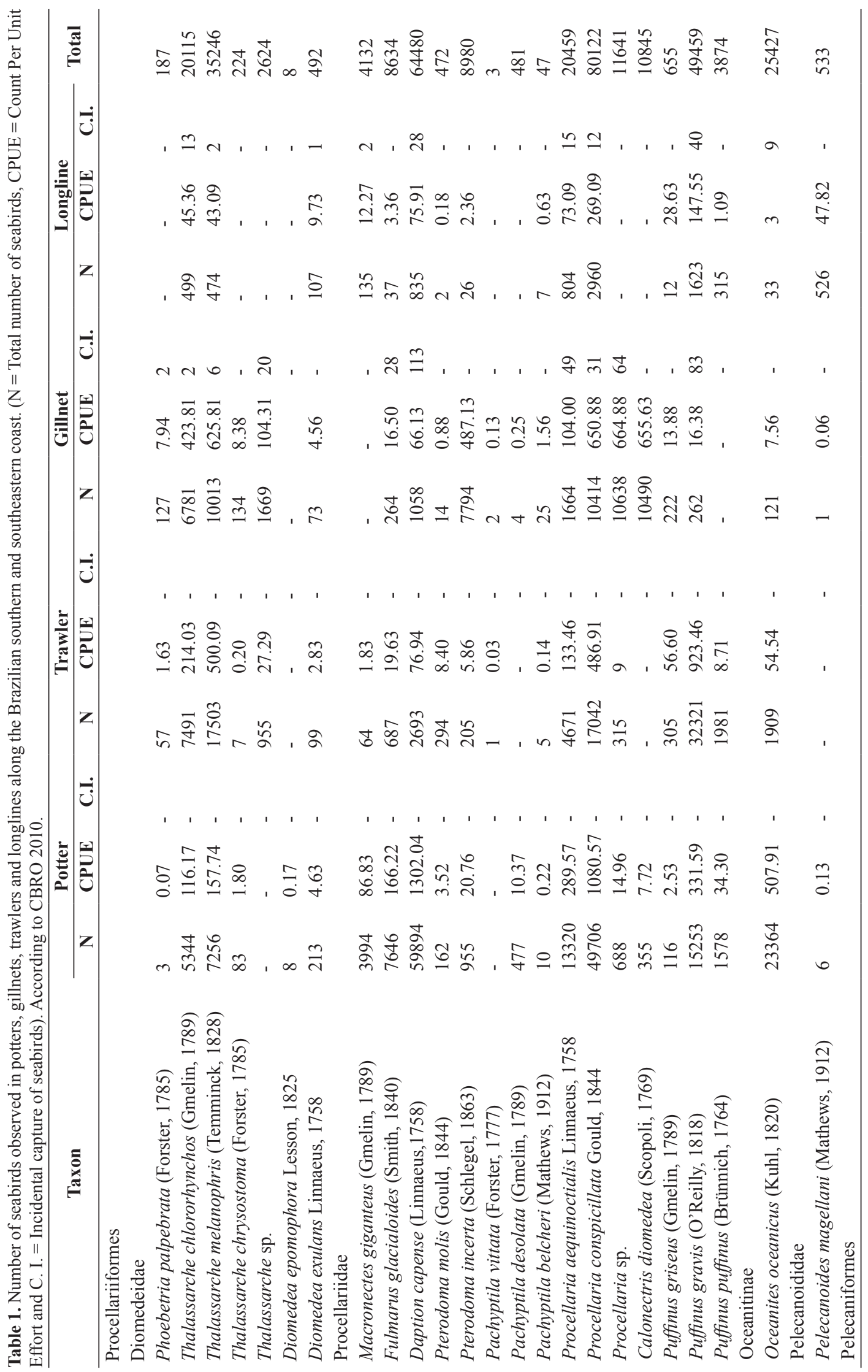




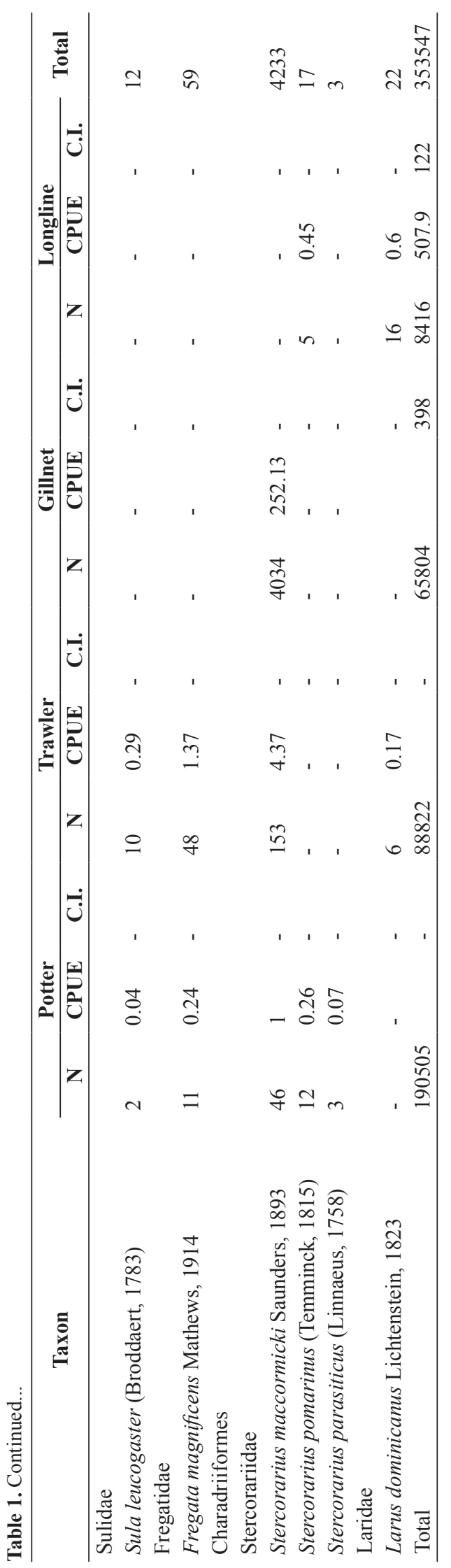




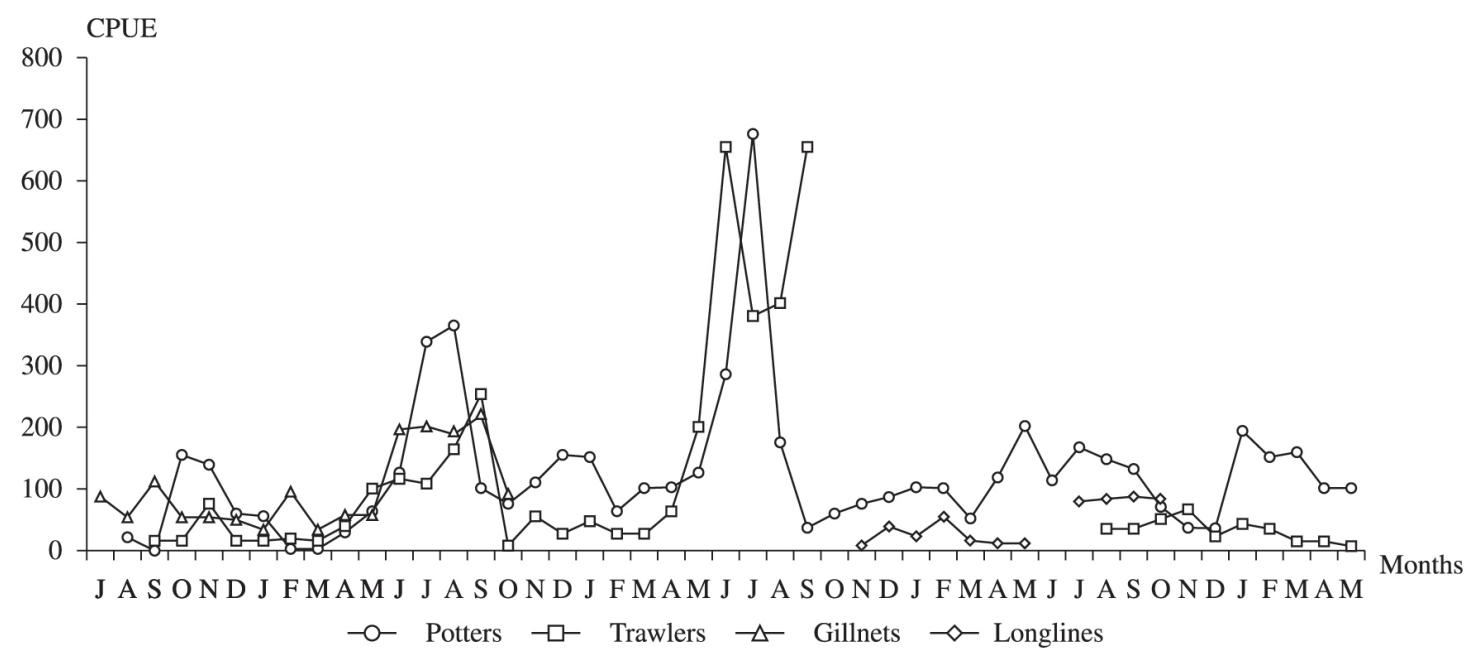

Figure 5. Seabird occurrence around potter, trawler, gillnet and longline vessels fishing off the southern coast of Brazil, from July 2001 to May 2005.

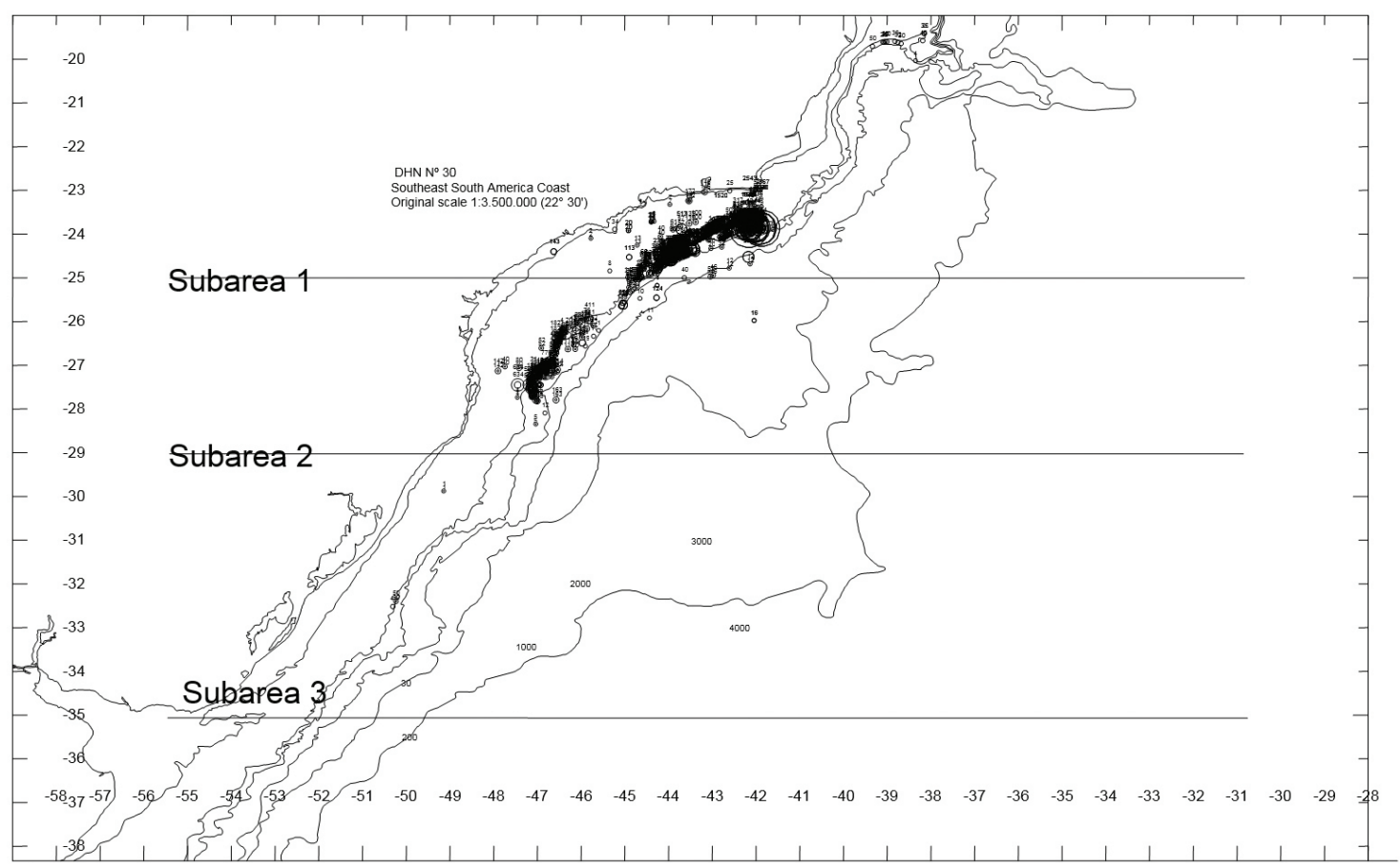

Figure 6. Occurrence of seabirds around trawler fishing operations, in three subareas along the Brazilian coast.

behaviour of different species as well as local conditions and the birds' experience (Weimerskirch et al., 2000).

The number of discarded species (75) by the fleet that served the south-southeastern Brazilian coast (GEP and CTTMar, 2005) was higher than that of the Mediterranean (32 taxa), 29 in the Ebro Delta and 47 in Baleartic waters, and the species most commonly discarded were Sardina pilchrdus (22.4) flatfish (19.1) and Trachurus spp. (17.3\%) (Martinez-Abraín et al., 2002).

In Kerguelen's region, fewer species were recorded of birds attracted around trawlers and long line vessels (24 taxa) than on the south-southeast Brazilian coast.
However, the number of birds was higher (497416) in 826 observations (Weimerskirch et al., 2000). Only 15 species were identified along the coast of Rio de Janeiro to a northerly direction (Coelho et al., 1990) and that number rises to 44 in a triangular section in the South Atlantic Ocean including South Georgia and the Strait of Magellan (Veit, 1995).

Several variables influence the number of species that are attracted to vessels, such as time in days from the start of fishing activities, the activity being developed, weather conditions (Weimerskirch et al., 2000), foraging behaviour, which avoids competition for the same resource (Chiaradia, 


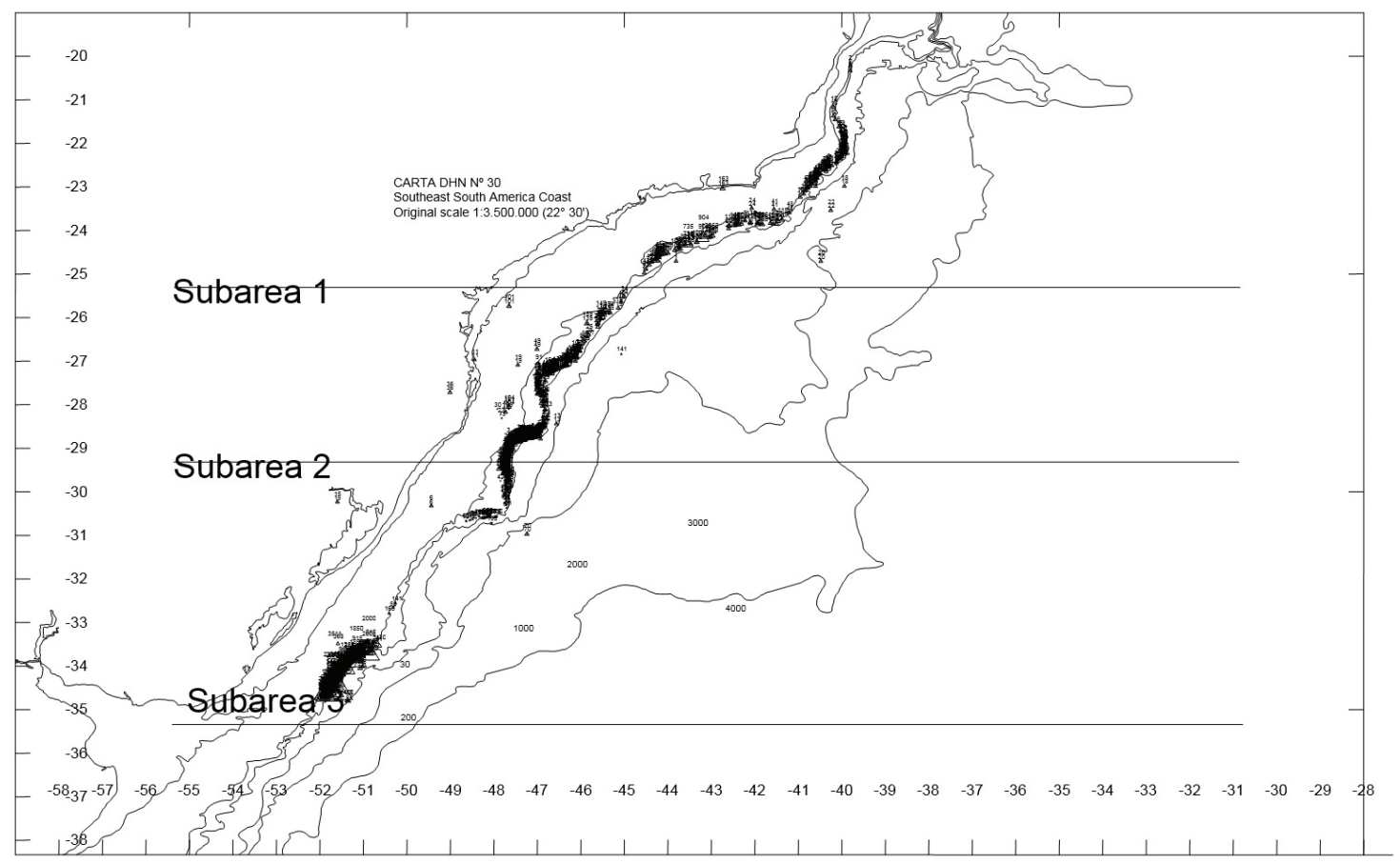

Figure 7. Occurrence of seabirds around potter fishing operations, in three subareas along the Brazilian coast.

Table 2. Total frequency of seabirds at oceanic fisheries off the southeastern Brazilian coast. (Independence test showed significant differences in all vessels operations).

\begin{tabular}{lcccc}
\hline \multicolumn{1}{c}{ Species } & Trawler & Potter & Gillnet & Longline \\
\hline D. exulans & 95 & 258 & 224 & 107 \\
T. melanophrys & 17398 & 8015 & 9976 & 474 \\
T. chlororhynchos & 7467 & 5412 & 7277 & 499 \\
T. crysostoma & 579 & 83 & 473 & 0 \\
Diomedea sp. & 383 & 8 & 1027 & 0 \\
M. giganteus & 64 & 3937 & 249 & 135 \\
F. glacialoides & 687 & 7631 & 1630 & 37 \\
D. capensis & 2669 & 59897 & 9717 & 835 \\
P. a. aequinoctialis & 4885 & 12966 & 10696 & 804 \\
P. a. conspicillata & 15859 & 52113 & 12153 & 2960 \\
P. puffinus & 1934 & 443 & 482 & 315 \\
P. gravis & 32015 & 18121 & 10301 & 1623 \\
O. oceanicus & 1754 & 23851 & 4209 & 559 \\
\hline
\end{tabular}

1991), dominance (Coelho et al., 1990) or positive or negative associations between them (Veit, 1995). The most abundant species in studies along the Brazilian coast were $D$ capense, T. clhororhynchos, $P$. aequinoctialis and P. gravis (Vooren and Fernandes, 1989; Coelho et al., 1990; Vaske-Júnior, 1991; Veit, 1995) corroborating the present study, with the participation of $P$. conspicilatta and $O$. oceanicus. For the different modalities, the influence of wind occurred in the abundance of species seen, with the biggest records for the northeasterly and southwesterly directions.

Potters attracted the greatest number of species and specimens on the southeastern and southern Brazilian coast, which could be explained by the higher number of counts or the area of operation of smaller length, and which may be subject to increased diversity and decreased productivity that occurs in the oceans. As in the study by Weimerskirch et al. (2000), the long line attract more birds by their disposal to be made in mixed mode, different from trawlers that have fewer discharges (whole fish was frozen) without bycatch or being thrown heterogeneously (tails, heads and bones).

Unlike that observed in trawler fleets, the distribution of birds that approached the gillnet was homogeneous, with the highest values occurring in Paraná and Santa Catarina, and potters and longlines in Rio Grande do Sul, 
Table 3. Species abundance by fishery type $(1=$ trawlers, $2=$ potters, $3=$ gillnet, $4=$ longline $)$ in relation to wind direction $(0=$ no wind, $1=$ northerly, $2=$ northeasterly, $3=$ northwesterly, $4=$ southerly, $5=$ southeasterly, $6=$ southwesterly, $7=$ easterly, $8=$ westerly).

\begin{tabular}{|c|c|c|c|c|c|c|c|c|c|c|c|}
\hline \multirow{2}{*}{ Species } & \multirow{2}{*}{ Vessels } & \multicolumn{9}{|c|}{ Wind direction } & \multirow{2}{*}{ Total } \\
\hline & & $\mathbf{0}$ & 1 & 2 & 3 & 4 & 5 & 6 & 7 & 8 & \\
\hline \multirow[t]{4}{*}{ D. exulans } & 1 & 0 & 17 & 42 & 0 & 7 & 5 & 0 & 24 & 0 & 95 \\
\hline & 2 & 1 & 24 & 87 & 3 & 25 & 17 & 41 & 48 & 12 & 258 \\
\hline & 3 & 0 & 9 & 30 & 6 & 152 & 6 & 14 & 3 & 3 & 223 \\
\hline & 4 & 0 & 11 & 22 & 2 & 18 & 14 & 21 & 14 & 5 & 107 \\
\hline \multirow[t]{4}{*}{ T. melanophris } & 1 & 737 & 241 & 7068 & 412 & 2529 & 2845 & 2486 & 869 & 211 & 17398 \\
\hline & 2 & 68 & 869 & 1593 & 524 & 942 & 862 & 1831 & 901 & 425 & 8015 \\
\hline & 3 & 738 & 785 & 3537 & 341 & 1245 & 848 & 1863 & 415 & 162 & 9934 \\
\hline & 4 & 0 & 46 & 118 & 12 & 89 & 26 & 125 & 18 & 40 & 474 \\
\hline \multirow[t]{4}{*}{ T. chlororhynchos } & 1 & 763 & 138 & 3027 & 248 & 737 & 1088 & 1008 & 383 & 75 & 7467 \\
\hline & 2 & 121 & 511 & 1170 & 221 & 802 & 520 & 719 & 774 & 574 & 5412 \\
\hline & 3 & 710 & 467 & 2533 & 100 & 969 & 963 & 948 & 515 & 67 & 7272 \\
\hline & 4 & 0 & 8 & 126 & 5 & 136 & 75 & 69 & 53 & 27 & 499 \\
\hline \multirow[t]{4}{*}{ D. crysostoma } & 1 & 0 & 85 & 32 & 0 & 36 & 0 & 426 & 0 & 0 & 579 \\
\hline & 2 & 0 & 2 & 34 & 0 & 33 & 4 & 5 & 2 & 3 & 83 \\
\hline & 3 & 110 & 3 & 75 & 0 & 10 & 109 & 44 & 102 & 20 & 473 \\
\hline & 4 & 0 & 0 & 0 & 0 & 0 & 0 & 0 & 0 & 0 & 0 \\
\hline \multirow[t]{4}{*}{ Diomede asp. } & 1 & 15 & 8 & 115 & 60 & 25 & 34 & 69 & 57 & 0 & 383 \\
\hline & 2 & 0 & 0 & 0 & 0 & 0 & 0 & 4 & 1 & 3 & 8 \\
\hline & 3 & 108 & 0 & 507 & 0 & 80 & 187 & 0 & 105 & 40 & 1027 \\
\hline & 4 & 0 & 0 & 0 & 0 & 0 & 0 & 0 & 0 & 0 & 0 \\
\hline \multirow[t]{4}{*}{ M. giganteus } & 1 & 18 & 5 & 9 & 0 & 0 & 0 & 21 & 0 & 11 & 64 \\
\hline & 2 & 4 & 629 & 752 & 216 & 409 & 210 & 962 & 389 & 366 & 3937 \\
\hline & 3 & 0 & 7 & 25 & 8 & 31 & 69 & 102 & 1 & 6 & 249 \\
\hline & 4 & 0 & 22 & 33 & 8 & 8 & 4 & 46 & 10 & 4 & 135 \\
\hline \multirow[t]{4}{*}{ F. glacialoides } & 1 & 311 & 5 & 51 & 0 & 1 & 45 & 266 & 1 & 7 & 687 \\
\hline & 2 & 14 & 1301 & 960 & 596 & 659 & 503 & 2016 & 546 & 1036 & 7631 \\
\hline & 3 & 1 & 60 & 658 & 109 & 170 & 109 & 464 & 39 & 20 & 1630 \\
\hline & 4 & 0 & 1 & 10 & 0 & 0 & 0 & 26 & 0 & 0 & 37 \\
\hline \multirow[t]{4}{*}{ D. capensis } & 1 & 466 & 124 & 771 & 22 & 92 & 295 & 681 & 91 & 127 & 2669 \\
\hline & 2 & 122 & 7352 & 10781 & 3274 & 6941 & 2688 & 18584 & 4034 & 6121 & 59897 \\
\hline & 3 & 90 & 511 & 3312 & 316 & 1002 & 1148 & 2480 & 578 & 180 & 9617 \\
\hline & 4 & 0 & 51 & 267 & 14 & 150 & 89 & 147 & 62 & 55 & 835 \\
\hline \multirow[t]{4}{*}{ P. a. aequinoctialis } & 1 & 132 & 222 & 2192 & 117 & 559 & 330 & 913 & 357 & 63 & 4885 \\
\hline & 2 & 28 & 1935 & 3039 & 757 & 1256 & 752 & 2891 & 1519 & 789 & 12966 \\
\hline & 3 & 544 & 985 & 3876 & 263 & 1370 & 824 & 2001 & 633 & 60 & 10656 \\
\hline & 4 & 1 & 40 & 149 & 28 & 141 & 145 & 168 & 56 & 76 & 804 \\
\hline \multirow[t]{4}{*}{ P. a. conspicillata } & 1 & 559 & 482 & 6024 & 495 & 1699 & 2499 & 2029 & 1401 & 571 & 15859 \\
\hline & 2 & 406 & 5557 & 13551 & 1691 & 7027 & 7327 & 5854 & 8522 & 2178 & 52113 \\
\hline & 3 & 819 & 493 & 4168 & 330 & 2252 & 1373 & 1494 & 1013 & 190 & 12132 \\
\hline & 4 & 2 & 89 & 1177 & 58 & 295 & 669 & 398 & 223 & 49 & 2960 \\
\hline \multirow[t]{4}{*}{ P. puffinus } & 1 & 56 & 64 & 1149 & 117 & 260 & 99 & 86 & 103 & 0 & 1934 \\
\hline & 2 & 10 & 2 & 125 & 0 & 121 & 86 & 43 & 31 & 25 & 443 \\
\hline & 3 & 11 & 0 & 109 & 0 & 96 & 24 & 108 & 108 & 23 & 482 \\
\hline & 4 & 0 & 46 & 107 & 25 & 6 & 79 & 43 & 6 & 3 & 315 \\
\hline \multirow[t]{4}{*}{ P. gravis } & 1 & 156 & 2021 & 13755 & 2332 & 1273 & 7678 & 3445 & 516 & 839 & 32015 \\
\hline & 2 & 182 & 2215 & 4371 & 872 & 1583 & 1420 & 2445 & 3788 & 1245 & 18121 \\
\hline & 3 & 473 & 332 & 4455 & 372 & 1230 & 825 & 1681 & 690 & 241 & 10299 \\
\hline & 4 & 0 & 25 & 549 & 7 & 234 & 390 & 123 & 244 & 51 & 1623 \\
\hline
\end{tabular}




\begin{tabular}{|c|c|c|c|c|c|c|c|c|c|c|c|}
\hline \multirow{2}{*}{ Species } & \multirow{2}{*}{ Vessels } & \multicolumn{9}{|c|}{ Wind direction } & \multirow{2}{*}{ Total } \\
\hline & & 0 & 1 & 2 & 3 & 4 & 5 & 6 & 7 & 8 & \\
\hline \multirow[t]{4}{*}{ O. oceanicus } & 1 & 38 & 12 & 521 & 120 & 389 & 334 & 246 & 92 & 2 & 1754 \\
\hline & 2 & 121 & 3804 & 5581 & 985 & 1984 & 2055 & 4001 & 2815 & 2505 & 23851 \\
\hline & 3 & 156 & 489 & 1696 & 52 & 529 & 456 & 484 & 307 & 40 & 4209 \\
\hline & 4 & 1 & 40 & 190 & 12 & 95 & 34 & 124 & 26 & 37 & 559 \\
\hline \multirow[t]{4}{*}{ Total } & 1 & 3351 & 3424 & 34756 & 3923 & 7607 & 15252 & 11676 & 3894 & 1906 & 85789 \\
\hline & 2 & 1077 & 24201 & 42044 & 9139 & 21782 & 16444 & 39396 & 23307 & 15282 & 192735 \\
\hline & 3 & 3860 & 4142 & 24983 & 1900 & 9140 & 6946 & 11689 & 4516 & 1060 & 68203 \\
\hline & 4 & 4 & 380 & 2750 & 174 & 1176 & 1530 & 1296 & 719 & 355 & 8348 \\
\hline
\end{tabular}

in the winter when the tropical front reaches the Brazilian south coast bringing nutrients from subantarctic waters, increasing biological productivity, coinciding with the peak of fishing effort in southern Brazil (Veit, 1995; Neves and Olmos, 1997).

The fishing gear trawler vessels and potters did not capture birds incidentally during the studied period, but the mortality in the region of Kerguelen was attributed to the equipment of Ukrainian trawlers (electronic connection between the network and the boat) that affect $P$. aequinoctialis and other petrels when trying to capture lost items on the bed or in the condenser portion in nets, also when starting or ending the operation (Weimerskirch et al., 2000).

Many studies of incidental capture have been underestimated by extensive sets of data acquired by observers untrained for reporting fishing mortality for birds (Murray et al., 1993; Klaer and Polacheck, 1997), or not dedicated to this function (Brothers, 1991; Neves and Olmos, 1997) as in this study. According to Weimerskirch et al. (2000), when the observer was watching the raising of the hooks, the number of captured birds was $0.25 \pm 0.33$ to $0.05 \pm 0.15$ when measuring fish were collected and the number of dead birds at the end were recorded.

Longline fishery is conducted on a major scale and many important features are captured by these vessels, since it is a conservation method, which tends to capture target species without causing destructive effects of bottom habitats with low fuel consumption (Lokkeborg, 1998). However, seabirds are caught when baited hooks are released and this can be a serious problem in the areas of fishing during certain periods in the North Atlantic (Degange and Day, 1991) and South (Weimerskirch and Jouventin, 1987; Brothers, 1991; Lokkeborg, 1998).

F. glacialoides is the largest representative of birds caught by longline in the North Ocean and in certain regions during certain periods, the birds can have a big impact on efficiency and profitability, becoming a major problem for fishermen (Lokkeborg, 1998). According to Weimerskirch et al. (2000) four species were caught, and P. aequinoctialis represented $91.8 \%$ of the total, followed by T. melanophris (35), D. chrysostoma (31) and D. exulans (12). The main species caught by demersal longline was P. gravis, seasonally common on the Brazilian coast and an efficient diver to catch on baited hooks, followed by T. melanoprhis (33), T. chororhynchos (17), P. aequinoctialis
(14), P. conspicillata (6) D. exulans (1) (Neves and Olmos, 1997), corroborating the present study.

The results from this study show that there is, indeed, an association between the type of fishing and the composition of birds sighted. However, some species such as $P$. $a$. conspicillata and $P$. gravis are the majority represented for all kinds of fishing. Therefore, it can be said that the results of positive association of species composition are the frequency of occurrence variation of other species recorded.

This study did not analyse the abundance of birds throughout the day; however, Neves and Olmos (1997) registered that the highest by-catch along the Brazilian coast occurred at dusk, while in the Northern Ocean, it was during the day since albatrosses are reported to feed at this stage (Harper, 1987; Weimerskirch and Wilson, 1992; Croxall and Prince, 1994) and the number of petrels caught that are also active at night is half of that during the day (Weimerskirch et al., 2000).

The results found in various parts of the world show the difficulty in accurately estimating the risk of extinction of small populations of long life cycle, despite the availability of long series of data that cannot sustain any level of incidental capture (Inchausti and Weimerskirch, 2001). Seasonal closures of fishing areas has been suggested around South Georgia (Croxall and Prince, 1990) and the Kerguelen Islands (Weimerskirch et al., 2000), since most of the catches were recorded in a short period of time and in a relatively small area. Lines posted using the toreline lost significantly fewer baits and captured fewer birds ( 0.04 birds/1000 hooks) than other methods, since those released without any artifacts captured 99 birds (1.75 birds/1000 hooks) and through tunnels submerged 28 birds (0.49) (Lokkeborg, 1998; Brothers, 1991). However, the use of this artifact appears to be inefficient in fishery in the Ukraine, where the start night was the most efficient method of waste containment, drastically reducing the incidental capture of petrels (Weimerskirch et al., 2000).

Because of the emphasis on the capture of swordfish and sharks, the night launch is standard procedure for many fishing vessels in Brazilian waters and probably contributes to the low rate in the observation of catches in tuna fishery (Chiaradia, 1991; Vaske-Júnior, 1991; Stagi et al., 1997). The lack of necessary knowledge in the seasonal distribution of seabirds in Brazilian waters added to the 
legal and financial difficulties, and uncertainty regarding the efficiency of closing areas makes this management tool impractical at the moment (Neves and Olmos, 1997).

Following the guidelines suggested by these authors, vessels working along the Brazilian coast used torelines, in-line weights and dyeing bait to minimise the incidental capture of albatrosses and petrels.

\section{Acknowledgements}

The Conselho Nacional de Desenvolvimento Científico e Tecnológico $(\mathrm{CNPq})$ partially supported the work of J.O.B and J.A.A.P. with productivity scholarships. The authors are indebted to all members of the Chartered Fleet Observers Program for their hard work and the quality of collected data. We also thank vessel owners, captains, and crew members of all monitored vessels for the support and good will during the long fishing trips.

\section{References}

ABRAMS, RW., 1983. Pelagic seabirds and trawl-fisheries in the Southern Benguela Current region. Marine Ecology Progress Series, vol. 11, p. 151-156. http://dx.doi.org/10.3354/meps011151.

ALVAREZ PEREZ, JA., PEZZUTO, PR., WAHRLICH, R. and DE SOUZA SOARES, AL., 2009. Deepwater fisheries in Brazil: history, status and perspectives. Latin American Journal of Aquatic Research, vol. 37, no. 3, p. 513-542. http://dx.doi.org/10.3856/ vol37-issue3-fulltext-18.

BARTLE, JA., 1991. Incidental capture of seabirds in the New Zealand subantarctic squid trawl fishery. Bird Conservation International, vol. 1, no. 4, p. 351-359. http://dx.doi.org/10.1017/ S0959270900000708

BRIGGS, KT., TYLER, WB., LEWIS, DB. and CARLSON, DR., 1987. Bird communities at sea off California: 1975 to 1983. Studies in Avian Biology, no. 11, p. 1-4.

BROTHERS, N., 1991. Albatross mortality and associated bait loss in the Japanese longline fishery in the Southern Ocean. Biological Conservation, vol. 55, no. 3, p. 255-268. http://dx.doi. org/10.1016/0006-3207(91)90031-4

CHIARADIA, A., 1991. Interação entre aves marinhas e cardumes de bonito listado (Katswonus pelamis) na costa sul do Brasil. Atlantica, vol. 13, no. 1, p. 115-118.

COELHO, EP., ALVES, VS., SONEGHET, MLL. and CARVALHO, FS., 1990. Levantamento das aves marinhas no percurso Rio de Janeiro - Bahia (Brasil). Boletim do Instituto Oceanográfico, vol. 38, no. 2, p. 161-167.

CROXALL, JP. and PRINCE, PA., 1990. Recoveries of Wandering albatrosses Diomedea exulans ringed at South Georgia 1958-1968. Ring \& Migration, vol. 11, no. 1, p. 43-51. http://dx.doi.org/10. 1080/03078698.1990.9673960.

CROXALL, JP. and PRINCE, PA., 1994. Dead or alive, night and day: how do albatrosses catch squid? Antarctic Science, vol. 6, no. 2, p. 155-162. http://dx.doi.org/10.1017/S0954102094000246.

DEGANGE, AR. and DAY, RH., 1991. Mortality of seabirds in the Japanese gillnet fishery for salmon. The Condor, vol. 93, no. 2, p. 251-258. http://dx.doi.org/10.2307/1368940.
FURNESS, RW., ENSOR, K. and HUDSON, AV., 1992. The use of fishery waste by gull populations around the British Isles. Ardea, vol. 80, no. 2, p. 105-113

GARTHE, S. and HÜPPOP, O., 1994. Distribution of shipfollowing seabirds and their utilization of discards in the North Sea in summer. Marine Ecology Progress Series, vol. 106, p. 1-9. http://dx.doi.org/10.3354/meps106001.

GARTHE, S., CAMPHUYSEN, K. and FURNESS, R., 1996. Amounts of discards by commercial fisheries and their significance as food for seabirds in the North Sea. Marine Ecology Progress Series, vol. 136, p. 1-11. http://dx.doi.org/10.3354/meps136001.

Grupo de Estudos Pesqueiros - GEP and Centro de Ciências Tecnológicas da Terra e do Mar - CTTMAR, 2005. Boletim estatístico da pesca industrial de Santa Catarina: ações prioritárias ao desenvolvimento da pesca e aqüicultura no Sul do Brasil: relatório final. Itajaí: UNIVALI. 61 p.

GRIFFITHS, AM., 1982. Reactions of some seabirds to a ship in the Southern Ocean. The Ostrich, vol. 53, no. 4, p. 228-235. http://dx.doi.org/10.1080/00306525.1982.9634579.

HARPER, PC., 1987. Feeding behaviour and other notes on 20 species of Procellariformes at sea. Notornis, vol. 34, no. 3, p. $169-192$.

HARRISON, P., 1996. Seabirds an identification guide. London: Christopher Helm A \& C Black. 448 p.

HUDSON, AV. and FURNESS, RW., 1989. The behaviour of seabirds foraging at fishing boats around Shetlands. Ibis, vol. 131, no. 2, p. 225-237. http://dx.doi.org/10.1111/j.1474-919X.1989. tb02765.x.

INCHAUSTI, P. and WEIMERSKIRCH, H., 2001. Risks of decline and extinction of the endangered Amsterdam albatross and the projected impact of long-line fisheries. Biological Conservation, vol. 100 , no. 3, p. 377-386. http://dx.doi.org/10.1016/S00063207(01)00044-1.

KLAER, N. and POLACHECK, T., 1997. By-catch of albatrosses and other seabirds by Japanese longline fishing vessels in the Australian fishing zone from April 1992 to March 1995. Emu, vol. 97, no. 2, p. 150-167. http://dx.doi.org/10.1071/MU97019.

LOKKEBORG, S., 1998. Seabird by-catch and bait loss in longlining using different setting methods. Journal of Marine Science, vol. 55 , p. 145-149.

MARTINEZ-ABRAÍN, A., MAESTRE, R. and ORO, D., 2002. Demersal trawling waste as a food source for Western Mediterranean seabirds during the summer. Journal of Marine Science, vol. 59, no. 3 , p. $529-537$.

MOORE, CC., 1994. Transect counts of pelagic seabirds in Azorean waters. Arquipélgago. Life Marine Science, vol. 12a, p. 111-116.

MURRAY, TE., BARTLE, JA., KALISH, SR. and TAYLOR, PR., 1993. Incidental capture of seabirds by Japanese southern bluefin tuna longline vessels in New Zealand waters, 1988-1992. Bird Conservation International, vol. 3, no. 3, p. 181-210. http:// dx.doi.org/10.1017/S0959270900000897.

NEVES, T. and OLMOS, F., 1997. Albatross mortality fisheries off the coast of Brasil. In ROBERTSON, G. and GALES, R. (Eds.). Albatross biology and conservation. Chipping Norton: Surrey Beatty \& Sons. p. 214-219.

ONLEY, D. and BARTLE, S., 1999. Identificacion de aves marinas de los Océanos del Sur: Una guía para observadores científicos a bordo de buques pesqueros. Hong Kong: Te Papa. 83 p. 
PEREZ, JAA. and WAHRLICH, R., 2005. A bycatch assessment of the gillnet monkfish Lophius gastrophysus fishery off southern Brazil. Fisheries Research, vol. 72, no. 1, p. 81-95. http://dx.doi. org/10.1016/j.fishres.2004.10.011.

PEREZ, JAA., WAHRLICH, R., PEZZUTO, P., SCHWINGEL, P., LOPES, FRA. and RODRIGUES-RIBEIRO, M., 2003. Deepsea Fishery off Southern Brazil: Recent Trends of the Brazilian Fishing Industry. Journal of Northwest Atlantic Fishery Science, vol. 31, p. 1-18.

PEZZUTO, PR., PEREZ, JAA. and WAHRLICH, R., 2006. Deepsea shrimps (Decapoda: Aristeidae): new targets of the deep-water trawling fishery in Brazil. Brazilian Journal of Oceanography, vol. 54, no. 2-3, p. 123-134. http://dx.doi.org/10.1590/S167987592006000200003 .

POCKLINGTON, R., 1979. An oceanographic interpretation of seabird distributions in the Indian ocean. Marine Biology, vol. 51, no. 1, p. 9-21. http://dx.doi.org/10.1007/BF00389026.

RIBIC, CA. and AINLEY, DG., 1989. Constancy of seabird assemblages: An exploratory look. Biological Oceanography, vol. 6 , no. 2, p. 175-202.

RYAN, PG. and MOLONEY, CL., 1988. Effect of trawling on bird and seal distributions in the southern Benguela region. Marine Ecology Progress Series, vol. 45, p. 1-11. http://dx.doi. org/10.3354/meps045001

STAGI, A., VAZ-FERREIRA, R., MARIN, Y. and JOSEPH, L., 1997. The conservation of albatrosses in Uruguayan waters. In ROBERTSON, G. and GALES, R. (Eds.). Albatross biology and conservation. Chipping Norton: Surrey Beatty \& Sons. p. 220-224.

THOMPSON, KR., 1992. Quantitative analysis of the use of discards from squid trawlers by black-browed albatrosses Diomedea melanophris in the vicinity of the Falklands Islands. Ibis, vol. 134, no. 1, p. 11-21. http://dx.doi.org/10.1111/j.1474919X.1992.tb07223.x.

THOMPSON, KR. and RIDDY, MD., 1995. Utilization of offal and discards from "finfish" trawlers around the Falklands islands by black-browed albatrosses Diomedea melanophris. Ibis, vol. 137, no. 2, p. 198-206. http://dx.doi.org/10.1111/j.1474-919X.1995. tb03240.x.
THOMSEN, H., 1962. Massas de água características del Oceano Atlântico: parte sudoeste. Buenos Aires: Secretaria de Marina Serviço de Hidrografia Naval. 28 p. (Reporte H. 632).

VASKE-JÚNIOR, T., 1991. Seabirds mortality on longline fishing for tuna in southern Brazil. Ciencia e Cultura, vol. 43, no. 5 , p. $388-390$.

VEIT, RR., 1995. Pelagic communities of seabird in the south Atlantic ocean. Ibis, vol. 137, no. 1, p. 1-10. http://dx.doi. org/10.1111/j.1474-919X.1995.tb03213.x.

VOOREN,CM. and FERNANDES, AC., 1989. Guia de albatrozes e petréis do sul do Brasil. Porto Alegre: Sagra. 99 p.

WAHRLICH, R., PEREZ, JAA. and LOPES, FRA., 2004. Aspectos tecnológicos da pesca do peixe-sapo (Lophius gastrophysus) com rede de emalhar no sudeste e sul do Brasil. Boletim do Instituto de Pesca, vol. 30, no. 1, p. 87-98.

WAUGH, SM., WEIMERSKIRCH, H., MOORE, PJ. and SAGAR, PM., 1999. Population dynamics of Black-browed and Greyheaded Albatrosses Diomedea melanophrys and D. chrysostoma at Campbell Island, New Zealand, 1942-96. Ibis, vol. 141, no. 2, p. 216-225. http://dx.doi.org/10.1111/j.1474-919X.1999.tb07544.x.

WEIMERSKIRCH, H. and JOUVENTIN, P., 1987. Population dynamics of the Wandering albatrosses, Diomedea exulans, of the Crozet Islands: causes and consequences of the population decline. Oikos, vol. 49, no. 3, p. 315-322. http://dx.doi.org/10.2307/3565767.

WEIMERSKIRCH, H. and WILSON, RP., 1992. When do wandering albatross Diomedea exulans forage? Marine Ecology Progress Series, vol. 86, p. 297-300. http://dx.doi.org/10.3354/ meps086297.

WEIMERSKIRCH, H., BROTHERS, N. and JOUVENTIN, P., 1997. Population dynamics of wandering albatross Diomedea exulans and Amsterdam albatross D. amsterdamensis in the Indian ocean and their relationship with longline fisheries: Conservation Implication. Biological Conservation, vol. 79, no. 2-3, p. 257-270. http://dx.doi.org/10.1016/S0006-3207(96)00084-5.

WEIMERSKIRCH, H., CAPDEVILLE, D. and DUHAMEL, G., 2000. Factors affecting the number and mortality of seabirds attending trawlers and long liners in Kerguelen area. Polar Biology, vol. 23, no. 4, p. 236-249. http://dx.doi.org/10.1007/ s003000050440. 